\title{
How Accurate and Ethical is the Information on your Hand Sanitizer?
}

\author{
Seun Ayad* \\ University of Ibadan, Nigeria \\ *Corresponding author: Seun Ayoade, University of Ibadan, Nigeria \\ To Cite This Article: Seun Ayad. How Accurate and Ethical is the Information on your Hand Sanitizer?. Am J Biomed Sci \& Res. 2021 - 13(6). \\ AJBSR.MS.ID.001928. DOI: 10.34297/AJBSR.2021.13.001928.
}

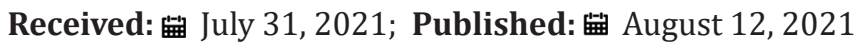

\section{Editorial}

I hold in my hand the bottle of hand sanitizer I applied before I started typing this letter to the editor. The label says, "kills $99.9 \%$ of germs". Really?! I hate to burst the bubble and rain on the parade of the millions of people using hand sanitizers in this sad season of the corona virus, but you have to know a secret. nobody has ever killed the corona virus or any other virus. Ever. If by killing, you mean irrevocably taking away life so the entity never comes back. When we use insecticides on insects they die and never come back. When a pet dog is run over by a truck and dies it never comes back. We never hear it bark or see it bite again. When a soldier is shot on the battlefield and dies, his life is over. His family and friends will never see him again. Is this what we do to the corona virus when we use hand sanitizers? No way. No way Jose! When we use hand sanitizers, we attack germs but do not kill them. We merely immobilize, denature and disable them-converting them from dangerous germs to innocuous cellular dust (microzymas). The germs will be back sooner or later. We kill viruses if we "kill" ice when we put salt on it, melting it to water. We "kill" viruses if we "kill" water when we boil it and turn it to vapour. It can still condense sooner or later. Viruses "die" if an egg "dies" when the chick steps out of it, later to lay another egg! The technical term for what happens to the germs when we attack them with antiseptics and antibiotics is known as "pleomorphism". If I manufactured hand sanitizers I would instruct my technical writers to inscribe "this product attacks and temporarily disables/denatures germs for your safety and good health" on the label. That would be an ethical, accurate and more realistic description of what hand sanitizers do. So now you better understand how we battle the corona virus when we use hand sanitizers. Even mainstream scientists that deny the existence of the microzymas (cellular dust) and adhere to the germ theory will admit this much- "the question is often posed, 'are viruses living?'. If to be living demands a cellular structure then the answer is that they are not" Page 19, Biological Science 3rd Edition, edited by R. Soper, Cambridge University press. But then, if viruses are not alive, how can we purport to kill them?

\section{References}

1. Bechamp, Blood and Its Third Anatomical Element, Kessinger Legacy Reprints

2. Mister SA (2018) Pleomorphism and Germ Terrain Dualism. JOJ Nurse Health Care 8(3): 555738. 